ROCZNIKI NAUK PRAWNYCH

Volume XXVIII, number $4-2018$

Englis h v e r s i o n

DOI: http://dx.doi.org/10.18290/rnp.2018.28.4-2en

MARZENA CZOCHRA

\title{
CONTENTIOUS ISSUES RELATED TO THE PERPETRATOR OF BODILY HARM OR A DISTURBANCE OF HEALTH IN A CONCEIVED CHILD
}

\section{PRELIMINARY REMARKS}

The intention of the Polish legislator is to protect not only the life and health of a born person, but also of a conceived human being, using the norm of Article 157a of the Penal Code. ${ }^{1}$ This provision is included in Chapter 19 entitled "Crimes against life and health." It directly follows the regulations concerning a mild, moderate and severe disturbance of health. Despite the structure of the chapter, the provision differs considerably from others serving to protect human life and health. In particular, the difference concerns the scope of protection prior and following birth. It is not possible to indicate all the differences concerning the provision in question. For this reason, our discourse will be limited only to discussing the subjective aspect of the offence under Article157a PC, both the existing regulations and proposals de lege ferenda. It seems correct to assume that in order to ensure effective protection during the prenatal phase and legislative consistency, unintentional bodily harm inflicted on a conceived child or a disturbance of health threatening the child's life should be subject to criminal liability.

To substantiate this proposition, we will analyse the attempts made so far in respect of amendment of Article 157a with regard to the regulation

Marzena Czochra, MA, is a doctoral student at the Department of Criminal Law, Institute of Law, Faculty of Law, Canon Law and Administration of the John Paul II Catholic University of Lublin (KUL); address: Al. Racławickie 14, 20-950 Lublin, Poland; e-mail: marzena.maria.cz@ interia.pl; https://orcid.org/0000-0002-4730-1324.

${ }^{1}$ Act of 6 June 1997-the Penal Code, Journal of Laws of 2017, item 2204 as amended [hereinafter referred to as $\mathrm{PC}]$. 
concerning the perpetrator of this crime, and further on three proposals for solutions to the problem at hand will be indicated.

\section{HISTORICAL BACKGROUND}

The protection of health and proper development of a conceived child is regulated by Article157a of the Polish Penal Code. This provision was added by Article 1 point 4 of the Act of 8 July 1999 amending the Penal Code and the act on the medical profession ${ }^{2}$ and has been in force in the Polish legal system since August 17, 1999. ${ }^{3}$ Such a solution already existed in the 1969 Penal Code. The difference between the current legal status and the previous one lies in a different approach to sanctions for the offence described in $\S 1$ and a different wording of $\S 2$. Previously, the offence was punishable by imprisonment for up to 2 years, and now the legislator has added a penalty of fine and imprisonment for up to 2 years. The difference also lies in the use of conjunctions at the end of the sentence in Article156a $\S 2$. Under the previous legislation, the exclusion of the criminality of the offence occurred where it was necessary to perform medical procedures required to avert a threat to both the life and health of a pregnant woman or a conceived child.

The provision adopted in its original version became void upon the entry into force of Act of 30 August 1996 amending the act on family planning, protection of the human foetus, and the conditions for termination of pregnancy and amending certain other acts. ${ }^{4}$ The repealing of Article156a of the 1969 Criminal Code was declared unconstitutional by the Constitutional Tribunal. ${ }^{5}$

Pursuant to the current wording of Article 157a PC, anyone who causes bodily harm to a conceived child or a disturbance of health threatening her life is subject to criminal liability. The criminality of the act was excluded with regard to a physician if the injury or disturbance of health of the conceived child is a consequence of medical actions necessary to avert a danger to the health or life of a pregnant woman or a conceived child (Art. 157a $§ 2$

\footnotetext{
${ }^{2}$ L. Gardocki, Prawo karne (Warszawa: Wydawnictwo C.H. Beck, 2017), 250.

${ }^{3}$ Act of 8 July 1999 amending the Penal Code and the act on the medical profession, Journal of Laws No. 64, item 729.

${ }^{4}$ Act of 30 August 1996 amending the act on family planning, protection of the human foetus and the conditions for termination of pregnancy and amending certain other acts, Journal of Laws of 1996, no. 139, item 646 .

${ }^{5}$ Judgement of the Constitutional Tribunal of 28 May 1997, file ref. no. K 26/96, OTK ZU of 1997, no. 2, item 19.
} 
PC). The clause of no conviction has been provided for the mother of a conceived child who commits an act under Article 157a $\S 3$.

The provision of Article 157a added by Act of 8 July 1999 amending the Penal Code and the act on the medical profession, remains unchanged, although attempts have been made to amend it.

One such attempt was made in the draft amendment to the Penal Code of 18 May 2007. ${ }^{6}$ The governmental draft assumed that the amended Article 157 a PC, in its paragraph 2, provided for punishability of unintentional bodily harm or a disturbance endangering the life of a conceived child. The sanction covers the qualified type in paragraph 3 . The qualified type occurred as a consequence of an act specified in Article 157a $\S 1$ or 2 , if a child was stillborn or died after birth. The perpetrator was to be liable to a penalty of imprisonment from 3 months up to 5 years. The exclusion of criminality was to apply not only to the physician, but also to another person authorised to perform medical treatment. The wording of the explanatory memorandum to this draft showed that a prerequisite for amending this provision was the need to strengthen the legal protection of human life and health in its prenatal phase. ${ }^{7}$ This proposal was not accepted.

On November 5, 2013, the Criminal Law Codification Committee presented a draft law amending the Penal Code and certain other acts. ${ }^{8}$ The Commission proposed to amend Article 157a PC and add Article 157b. It was proposed that the protection stipulated by Article 157a cover "a conceived child who is incapable of independent existence outside the mother's organism." It was also proposed to change the nomenclature of the effect of the offence to "damage to health threatening its life." The drafter took this term to mean "an impairment of bodily functions or a disturbance of health." It was demanded that the unintentional "perpetrator who was responsible for the care of a conceived child who was incapable of independent existence outside the mother's organism" should be penalised. As a novelty, an application procedure was introduced for the prosecution of the offence in question, considering the psychological conditioning, that is, the

\footnotetext{
${ }^{6}$ Draft law amending the Penal Code and certain other acts together with draft executive acts of 18 May 2007, $5^{\text {th }}$ Sejm, Sejm paper no. 1756; accessed December 26, www.sejm.gov.pl.

${ }^{7}$ Explanatory memorandum to the draft act amending the Penal Code and certain other acts together with draft executive acts of 18 May 2007], $5^{\text {th }}$ Sejm, Sejm paper no. 1756, p. 78; accessed December 27, 2017, www.sejm.gov.pl.

${ }^{8} \mathrm{https}$ ://bip.ms.gov.pl [accessed December 27, 2017].

${ }^{9}$ Explanatory memorandum to the draft act amending the Penal Code, Czasopismo Prawa Karnego i Nauk Penalnych 17, no. 4 (2013): 76-77.
} 
"traumatic nature of the experiences related to the event as well as the possible harm to the health of a pregnant woman." $"$ The entities entitled to submit such an application were to be the mother or father of the conceived child. The intention of the Codification Committee was to add Article 157b, which would be an equivalent of the current Article 157a § 2 PC, except that the proposal assumed that a danger to life or health was to threaten not only the pregnant woman, but also another child conceived in the event of a multiple pregnancy. However, the proposed amendments did not enter into force.

Another attempt to amend the provision on the protection of a child conceived was made on August 19, 2016. At that time, the Sejm received a civic draft law amending the Act of 7 January 1993 on family planning, protection of the human foetus and the conditions for termination of pregnancy and the Act of 6 June 1997-the Penal Code. The provision of Article 2 point 5 of this draft provided for penalisation of unintentional bodily harm to a conceived child or a disturbance of health that endangers her life. It was also proposed that the court should be able to apply extraordinary commutation in relation to the mother who would act intentionally, or even waive the sentence. This proposal was also rejected.

For this reason, our discourse addresses the issue of the legitimacy of amendments to Article157a of the Penal Code by introducing punishability of offences committed unintentionally. The justification for the extended scope of protection of health of a conceived child during the prenatal life stems directly from the regulations contained in the Constitution of the Republic of Poland. ${ }^{11}$ The provision of Article 38 of the Constitution of the Republic of Poland states that the Republic of Poland shall ensure the legal protection of the life of every human being. Moreover, pursuant to Article 32 $\S 1$ thereof everyone is equal under the law. Everyone has the right to equal treatment by public authorities. Everyone has the right to have their life protected - this value is not subject to differentiation. ${ }^{12}$ In accordance with Article 68 of the Constitution of the Republic of Poland, everyone has the right to have their health protected. Public authorities are obliged by to ensure equal access to publicly funded health care services to citizens, regard-

\footnotetext{
${ }^{10}$ Ibid., 77

${ }^{11}$ The Constitution of the Republic of Poland of 2 April 1997, Journal of Laws No. 78, item 483, as amended.

${ }^{12}$ Judgement of the Constitutional Tribunal of 7 January 2004, file ref. no. K 14/03, OTK ZU no. 1/A/2004, item 23 .
} 
less of their financial situation. Public authorities are obliged to provide special health care to children, pregnant women, the disabled and the elderly.

The fact of extending the protection of life and health to the prenatal phase is confirmed by the Convention on the Rights of the Child, ${ }^{13}$ ratified by Poland. The preamble to the Convention indicates (referring to the Declaration of the Rights of the Child) that "the child, by reason of his physical and mental immaturity, needs special safeguards and care, including appropriate legal protection, before as well as after birth." The States-Parties to the Convention were obliged, among others, to provide mothers with appropriate health care in the period before and after childbirth.

Despite such a structure of international law regulations and provisions of constitutional importance, as well as the proposed acts amending the wording of Article 157a PC, as we mentioned above, this provision has not been modified.

\section{THE STRUCTURE OF THE OFFENCE UNDER ARTICLE 157A OF THE PENAL CODE}

The subject of protection provided for in Article 157a of the Penal Code is the life and health of a conceived child and the right of the parents of the child developing in the mother's uterus to its proper development. ${ }^{14}$ The scope of protection also includes the embryo. ${ }^{15}$ As the linguistic interpretation of Article 157a indicates, the legislator did not make a distinction between the embryo prior to and following implantation. What is more, importantly, every embryo, regardless of its development phase, is covered by protection.

The offence under Article 157a $\S 1 \mathrm{PC}$ has a universal nature. It may be committed through an act or omission. An omission occurs when it is committed by an offender who is under the specific obligation not to allow it to happen $^{16}$ (which demonstrates the individual nature of the offence). The

\footnotetext{
${ }^{13}$ Convention on the Rights of the Child, adopted by the United Nations General Assembly on November 20, 1989, Journal of Laws 1991, no. 120, item 526.

${ }^{14}$ J. GIEZEK, "Rozdział XIX. Przestępstwa przeciwko życiu i zdrowiu," in Kodeks karny. Część szczególna. Komentarz, edited by Jacek Giezek (Warszawa: Wolters Kluwer Polska, 2014), 226.

${ }^{15}$ A. GÓRSKI, "Prawnokarne problemy określania relacji lekarz-pacjent z uwzględnieniem orzecznictwa Sądu Najwyższego (kwestie ogólne)," in Studia i Analizy Sądu Najwyższego, ed. K. Ślebzak (Warszawa: Lex a Wolters Kluwer business, 2012), 6: 314.

${ }^{16}$ A. MAREK, Kodeks karny. Komentarz (Warszawa: Wolters Kluwer Polska, 2006), 323.
} 
provision of Article 157a $\S 2$ excludes the criminality of the act if the injury or a disturbance of the health of a conceived child results from medical procedures carried out by a physician and which are necessary to avert a threat to the health or life of a pregnant woman or a conceived child. The consequence of an injury or a disturbance of health of a conceived child cannot be intended by the physician, although it can be predicted. ${ }^{17}$ However, Article $157 \mathrm{a} \S 3$ excludes punishability of this act committed by the mother of a conceived child. It should be stressed that in this case the Act excludes punishability but not unlawfulness.

The protection of a child in its prenatal phase starts with the conception and lasts until the delivery. This implies that, according to the Supreme Court's case law, protection is maintained until the labour pains ensue or, if a caesarean section is requested by the pregnant woman, from the moment when the initial medical procedure is started leading directly to the section, or when there are medical indications for the performance of a caesarean section, or in the case of any other alternative method from the occurrence of medical indications justifying such a necessity. ${ }^{18}$

The crime under Article 157a $\S 1 \mathrm{PC}$ is a substantive offence. Therefore, for criminal liability to occur, an effect in the form of bodily injury or health disturbance must be present. ${ }^{19}$ Injury to the body involves anatomopathological changes, whereas a disturbance of health is an interference with the functioning of an organ or its systems. ${ }^{20}$ In order for a crime to occur, there must be an effect, that is, an injury to the unborn child (even the slightest damage) or a disturbance to its health, but only one that threatens the life of the conceived child. ${ }^{21}$ This interpretation differs from the one used in Articles 156-157 PC, because these provisions regulate the effect in the form of disorder of health, which need not endanger human life. ${ }^{22}$

\footnotetext{
${ }^{17}$ A. ZoLL, Komentarz do Article157a k.k., LEX/el. 2013 no. 172271.

${ }^{18}$ Decision of the Supreme Court of 30 October 2008, file ref. no. I KZP 13/08, OSNKW of 2008, no. 11, item 90.

${ }^{19}$ M. NYKIEL, "Nieumyślne przestępstwa aborcyjne-uwagi de lege ferenda na marginesie wyroku SN-Izba Karna z 27 wrzesień 2010 r. (V KK 34/10)," Czasopismo Prawa Karnego i Nauk Penalnych 16, no. 2 (2012), 80.

${ }^{20}$ T. MARCinKowsKi, Medycyna sądowa dla prawników (Szczytno: Wyższa Szkoła Policji w Szczytnie, 2010), 78.

${ }^{21}$ M. SzwarczYK, "Część szczególna. XIX. Przestępstwa przeciwko życiu i zdrowiu. Art. 157a. Uszkodzenie ciała dziecka poczętego," in Kodeks karny. Komentarz, ed. T. Bojarski (Warszawa: LexisNexis, 2012), 362; similarly in Ł. CZEBotAR and Z. GĄDZIK, "Prawnokarna ochrona życia i zdrowia dziecka poczętego w ustawodawstwie polskim,” Kościót i Prawo 2 (2013), 262.

${ }^{22}$ See Art. 157 § 1: "Any person who causes an impairment of bodily functions or disturbance of health, other than the one specified in Article $156 \S 1$, is liable to imprisonment lasting from 3 months
} 
The offence specified in Article 157a PC, in contrast to the offences addressed by Articles 156 and $157,{ }^{23}$ can only be committed intentionally with a direct or possible intent. ${ }^{24}$ In one of its judgements, the Court of Appeal in Gdańsk argued: "The intention of a perpetrator in relation to the crime committed is determined by his or her psychological attitude when the criminal activity is started or when the attitude emerges during the perpetration." 25 To attribute guilt to an offender, it must be established that he or she acted with the intention of causing effects in the form of bodily injury regardless of its severity and a disturbance of health threatening the life of the conceived child. ${ }^{26}$

\section{THE RATIO LEGIS FOR AMENDING ARTICLE 157A OF THE PENAL CODE}

The legislator has not provided for unintentional commission of an offence causing impairment of the health of a conceived child. Therefore, the act in question remains unpunished if it results from negligence or recklessness, which seems to be a peculiar inconsistency on the part of the legislator in the light of other provisions of Chapter 19 protecting health, and in particular Articles 156 and 157 of the Penal Code. The observation that protection of a conceived child under criminal law is diminished seems to be justifiable. ${ }^{27}$ It seems that situations in which such an act could be committed unintentionally are not only in the sphere of theoretical considerations, but may occur in practice. Such an act may be the consequence of an act or omission of a physician who failed to exercise reasonable caution, for example, by not performing or improperly performing diagnostic procedures, which resulted

to 5 years. $\S 2$. Any person who causes an impairment of bodily functions or health disturbance lasting no longer than 7 days is liable to a fine, the restriction of liberty or imprisonment of up to 2 years."

${ }^{23}$ K. WiAK, "Część IV. Część szczególna. Rozdział III. Przestępstwa przeciwko życiu i zdrowiu. $\S 126$. Spowodowanie uszczerbku na zdrowiu (art. 156-157a k.k.)," in Prawo karne, ed. A. Grześkowiak (Warszawa: Wydawnictwo C.H. Beck, 2012), 319.

${ }^{24}$ Ibid., Ochrona dziecka poczętego w polskim prawie karnym (Lublin: Redakcja Wydawnictw Katolickiego Uniwersytetu Lubelskiego, 2001), 253.

${ }^{25}$ Judgement of the Court of Appeal in Gdańsk of 27 April 2017, ref. no. II Aka 95/17, LEX no. 2372259.

${ }^{26}$ D. KARKOwSKA, Prawo ochrony zdrowia $w$ pytaniach $i$ odpowiedziach-prawa pacjenta (Warszawa: Wolters Kluwer, 2008), 64.

${ }^{27}$ MAREK, Kodeks karny, 323. Similarly in R. KRAJEWSKI, Prawa i obowiazki seksualne matżonków. Studium prawne nad norma i patologia zachowań (Warszawa: Wolters Kluwer, 2009), 273. 
in a disturbance of health. ${ }^{28}$ That such situations are possible is demonstrated by the factual state which served as the basis for the judgement of the Grand Chamber of the European Court of Human Rights in the case of Vo vs. France of 8 July 2004. ${ }^{29}$ The complainant, Ms Thi-Nho Vo, was six months pregnant and went to a physician for a routine check-up. On the same day, a woman with a similar surname reported to the same medical centre, who was going to have her intrauterine device removed. Without examining the complainant, the physician proceeded directly to remove the coil, but his patient was the applicant, whose command of French was poor. The physician realised his mistake, but this became clear after the uterus was incised and the amniotic fluid was released. Since the water was not replenished, the foetus died. This case demonstrates that it is possible to cause the death of a conceived child unintentionally, so it is all the more possible to cause harm to its body or disrupt its health unintentionally. Perhaps, if the foetal water had been replenished in time, the woman's child might have survived, but it might have turned out that nevertheless bodily harm occurred. If that situation were to be assessed under the Polish Penal Code, such conduct would be unpunished. It seems that the above mentioned exemplification of factual states clearly demonstrates the significance of the problem and the need to regulate this issue.

Proposing any changes in the law, it is necessary to answer the question whether they are necessary and whether, in the name of legal certainty, it would not be more desirable to maintain the current shape of Article 157a PC. While penalising an act, it should be remembered that criminal law is the ultima ratio in the catalogue of measures available to the legislator. Penal measures serving to protect certain values must also be used in accordance with the principle of proportionality. These doubts are all the greater because both physicians and medical care workers can be held liable using either the ex delicto or ex contracto principle. ${ }^{30}$ However, it should noted that, in accordance with the Constitutional Tribunal's decision of 1997, life is an interest of extreme value, which should be protected by the Constitu-

\footnotetext{
${ }^{28}$ MAREK, Kodeks karny, 323.

${ }^{29}$ Judgement of the Grand Chamber of the European Court of Human Rights in the case of Vo v. France, 8 July 2004, application no. 53924/00; accessed January 3, 2018, https://hudoc. echr.coe.int/eng.

${ }^{30}$ D. KARLIKOWSKI, "Odpowiedzialność cywilna placówki medycznej a odpowiedzialność cywilna lekarza-zarys problemu w kontekście analizy przypadku," Rozprawy Ubezpieczeniowe 18, no. 1 (2015): 32 .
} 
tion at every stage of its development, including the earliest stages of life. ${ }^{31}$ In this judgement, the Tribunal noted that "the protection of human life cannot be understood solely as protection of the minimum biological functions essential for existence, but as a guarantee of proper development and the achievement and maintenance of a normal psychophysical state appropriate for a given developmental age (life stage)." In view of the above arguments, it must be concluded that human life and health, starting with the prenatal phase onwards, are values safeguarded by the Constitution.

In a democratic state of law, issues related to these legal values need to be regulated comprehensively. It is not sufficient to regulate them merely under civil law. In accordance with the constitutional principle of proportionality, the view that human health, including the health of the conceived child, must be protected against unintentional acts should be recognised as legitimate. Criminal law is a last resort; it is used when necessary, that is, when other legal measures are insufficient. Indeed, it should be borne in mind that, when introducing various kinds of restrictions on the rights and freedoms of the individual, only those measures which will be more onerous in a degree not greater than necessary should be chosen. ${ }^{32}$ However, the protection provided should be commensurate with the value of the protected interests. ${ }^{33}$ It is essential to protect the individual's rights to life and health at every stage of life development. Wherever the life and health of a human being - from the prenatal phase onwards - are jeopardised, criminal law must be applied. One must not make a distinction or judge these interests in relation to a born person and a human being which is not yet born but already conceived. These legal interests are so important that they call for full legal protection, therefore a recourse should be made to criminal law.

\section{DRAFT SOLUTIONS REGARDING THE PERPETRATOR OF THE OFFENCE OF ARTICLE 157 § 1 OF THE CRIMINAL CODE}

The solution to this problem can be threefold. The first and the simplest way-while guaranteeing the most comprehensive protection of life and health in the prenatal phase-would be to add a new provision of Article

\footnotetext{
${ }^{31}$ Decision of the Constitutional Tribunal of 28 May 1997, file ref. no. K 26/96.

32 Judgement of the Constitutional Tribunal of 1 June 1999, file ref. no. SK 20/98, OTK ZU of 1999 , no. 5 , item 93 .

${ }^{33}$ Judgement of the Constitutional Tribunal of 9 October 2001, file ref. no. K 8/00, OTK ZU of 2001, no. 7, item 211.
} 
157a $\S 1 \mathrm{a}$ of the Penal Code: "If the perpetrator acts unintentionally, he shall be subject to a fine, a penalty of restriction of liberty, or imprisonment for up to one year." ${ }^{34}$ This would be in line with the solutions proposed in the draft act amending the Penal Code and certain other acts together with the draft implementing acts (Sejm paper no. 1756). In the draft act mentioned above, a stricter deprivation of liberty was proposed-up to 2 years, however, the essence of the act consists lies in the punishability of unintentional prohibited acts which fulfil the criteria provided by Article 157a PC. Moreover, the proposed penalty is the same as the solution adopted in Article 157 $\S 3 \mathrm{PC}$, so the proposal seems to be coherent in legislative terms.

It can be claimed that the first proposed solution would not be overly restrictive, because in order to impute unintentional guilt to a perpetrator it would have to be determined that he or she was aware or at least predicted or, failing to predict, could have foreseen the possibility that a specific conduct might fulfil the criteria of a prohibited act. ${ }^{35}$ It is rightly assumed that the reason for committing unintentional offences is the failure to observe principle of reasonable caution. ${ }^{36}$ Therefore, in order for the offender to be held criminally liable, it is necessary to indicate which precautionary principle has been infringed, demonstrate the very infringement, and demonstrate the prediction of an offence or the possibility of predicting. ${ }^{37}$ In its decision of November 5, 2014, the Supreme Court reasoned: "For a correct determination of unintentionality, it is not enough to demonstrate the general recklessness of conduct. It becomes necessary to indicate a particular precautionary principle which has been infringed, as a result of which a prohibited act was committed. ${ }^{38}$ Seeing this in light of factual states related to an injury or a disturbance of health of a conceived child, it should be noted that the physician who has committed a prohibited act unintentionally is obliged to prove whether the rules of good medical practice have been broken and, if so, whether a breach of the precautionary principle required in a given situation can therefore be attributed to the offender. ${ }^{39}$ Liability for unintentionally

\footnotetext{
${ }^{34}$ Ibid: KRAJEWSKI, Prawa i obowiazki seksualne matżonków, 273; MAREK, Kodeks karny, 323.

${ }^{35}$ Judgement of the Supreme Court of 18 July 2007, file ref. no. WA 27/07, OSNwSK of 2007, no. 1, item 1682.

${ }^{36}$ A. GRZEŚKowiaK, "Rozdział I. Zasady odpowiedzialności karnej," in Kodeks karny. Komentarz, ed. A. Grześkowiak and K. Wiak (Warszawa: Wydawnictwo C.H. Beck, 2017), 108.

${ }^{37}$ S. ŁAGODZIŃski, "Przestępstwo nieumyślnego spowodowania śmierci człowieka (art. 155

k.k.). Rozważania teoretyczne i praktyka ścigania," Prokuratura i Prawo 7-8 (2014): 63.

${ }^{38}$ Decision of the Supreme Court of 5 November 2014, file ref. no. V KK 162/14.

${ }^{39}$ Decision of the Supreme Court of 11 October 2016, ref. no. III KK 123/16.
} 
inflicting bodily harm or causing a disturbance of health that endanger the life of a conceived child can be effected only if the offender can be imputed with violating the rules of caution in dealing with such important values as human life and health. This will apply not only to the so-called conscious unintentionality, ${ }^{40}$ but also to cases where the perpetrator could have foreseen the possibility of committing an offence. The solution is optimal because it is legislatively coherent: it does not give rise to any doubts as to its interpretation and also provides for general protection, since anyone can be held criminally liable. The proposed provision posits a type of common criminal offence while not limiting its scope only to certain causative actions. It seems, therefore, that the protection of the values of the life and health of the unborn would be equated (in terms of bodily harm and disturbance of health) with the protection of these interests after birth. Liability for unintentional bodily harm inflicted on a conceived child is called for by the doctrine, but no proposal containing such a change has been implemented.

In addition to the proposal mentioned above, other solutions may be considered, for example, taking into account the construction of the so-called hybrid guilt. Choosing the latter option, the wording of Article 157a $\S 1 \mathrm{a}$ PC could be as follows: "Whoever, even if unintentionally, violates the precautionary rules in force by performing therapeutic activities and unintentionally causing bodily harm to a conceived child or a disturbance of health threatening its life, shall be subject to a fine, restriction of liberty or imprisonment for up to one year." In this way, the effect would be unintentional, but the breach of the precautionary rules would be at least unintentional, so that the rules in question could also be infringed intentionally. In order to justify such a solution, a number of general observations on mixed guilt should be made. This type of construction is used by the legislator for types of acts qualified by the consequence, which results directly from Article 9 $\S 3$ PC. The consequence of a prohibited act committed by a perpetrator results from unintentional fault because he or she predicted this consequence or could have predicted. ${ }^{41}$ The key element of this form of guilt is that the intention of the perpetrator concerns only a certain part of the elements of the prohibited act, while unintentional negligence concerns the second part

\footnotetext{
${ }^{40}$ E. Hryniewicz-LaCH, "Przestępstwa z niewiedzy lub zapomnienia," Ruch Prawniczy, Ekonomiczny i Socjologiczny 77, no. 4 (2015), 175.

${ }^{41}$ W. CIEŚLAK, Prawo karne. Zarys instytucji i naczelne zasady (Warszawa: Wolters Kluwer, 2010), 105.
} 
of the offence. ${ }^{42}$ The proposal to limit causal activities only to "therapeutic activities" is associated with the current wording of Article $157 \mathrm{a} \S 2$ PC. Pursuant to Article 3 of the Act of 15 April 2011 on medical activity, ${ }^{43}$ medical activity consists in providing health services which may be provided through ICT systems or communication systems. Medical activities may include promotion of health, didactic and research tasks in connection with the provision of health services and health promotion, including the implementation of new medical technologies and treatment methods. This concept also includes all activities related to the treatment process, that is also diagnostics and prophylaxis. ${ }^{44}$ In order to attribute this offence to the perpetrator, it would be necessary to prove each time in criminal proceedings that the precautionary principles were violated, indicate which rules were breached as well as proving that the perpetrator's conduct was contrary to the current state of knowledge and that the result in the form of bodily injury or a disturbance of health was a foreseeable normal consequence of the perpetrator's activity. According to Article 4 of the Act of 5 December 1996 on the professions of physician and dental surgeon, ${ }^{45}$ a physician is obliged to practise his profession in accordance with the indications of current medical knowledge, available methods and means of prevention, diagnosis and treatment of diseases in accordance with the principles of professional ethics and with due diligence. Moreover, to find the perpetrator guilty, it is necessary to determine the guilt and causal link between the perpetrator's behaviour and the result. ${ }^{46}$

The third possible solution refers to the draft act of 5 November 2013 amending the Penal Code and certain other acts submitted by the Criminal Law Codification Commission. The third option could read as follows: "§ 1a. If the perpetrator who was obliged to provide care to a conceived child unintentionally causes bodily harm to the conceived child or a disturbance of health threatening its life, the offender shall be subject to the penalty of a fine, restriction of liberty or imprisonment for up to one year." This change posits an individual offence, since only the offender who is responsible

\footnotetext{
${ }^{42}$ GARDOCKI, Prawo karne, 89.

${ }^{43}$ Act of 15 April 2011 on medical activity, Journal of Laws No. 112, item 654.

${ }^{44}$ A. WoŁoszYn-Cichocka and G. LubeŃCZuk, "Działalność lecznicza-pojęcie oraz formy i zasady wykonywania," Studia Iuridica Lublinensia 23 (2014): 69.

${ }^{45}$ Act of 5 December 1996 on the professions of physician and dental surgeon, Journal of Laws of 1997, no. 28, item 152.

${ }^{46}$ M. WOLIŃSKa, "Odpowiedzialność karna lekarza za błąd w sztuce lekarskiej," Prokuratura i Prawo 5 (2013), 27-28.
} 
for the care of a conceived child would be criminally liable. The entities responsible would be physicians and other medical workers, as well as any person who guaranteed safety of the conceived child, for example the father. With this solution, the perpetrator would act unintentionally. The duty of care would result from the law or the position held (e.g. nurse). The duty of care is linked to the guarantor's function, which considerably reduces the protection of the life and health of the conceived child. Given such wording, the content of the provision of Article 157a $\S 3$ PC should be adjusted as follows: "The mother of a conceived child who commits an act specified in paragraphs 1 and $\S 1$ a shall not be subject to a penalty."

Each of the above proposals concerning the addition of the new paragraph 1a to Article 157a of the Penal Code would affect the current provision of paragraph 2. Holding a physician in this particular case liable seems to be extremely harsh and could put too much strain on physicians who save the life and health of both a pregnant woman and her conceived child. Therefore, it would seem justifiable if the current paragraph 2 provided that a physician does not commit a crime, either intentionally or unintentionally, if he or she acts in the manner described in that provision. However, a physician who does not meet the conditions specified in Article 157a § 2 PC is liable for both intentional and unintentional acts.

In conclusion, it appears that the fullest protection is ensured by introducing a solution which builds on the already existing solutions for serious, moderate and mild harm to human health (the first proposal). The change in the first option, that is, the addition of a provision according to which unintentional acts would be punishable by criminal law, would be justified by systemic reasons. It would show the consistency of the legislator and the coherence of the legal system. However, any such postulate has turned out to be ineffective. Perhaps this results from the subjective approach which is too broad. For this reason, this discourse presents other possible proposals for change.

The second and third concepts of change (i.e. the introduction of the socalled hybrid guilt or the criminalisation of a perpetrator who is responsible for the care of the conceived child) only partially overlap with the first proposed amendment and are limited to the penalisation of unintentional damage to the body of a conceived child or a disturbance of health threatening its life. The limitation of criminal liability only to certain entities does not ensure the equality of legally protected interests and such solutions still evaluate the interests in question and make the level of their protection conditional on the 
moment of birth. Neither the second nor the third proposal provides for such aspects as an inadvertent mechanical injury resulting from a traffic accident involving a pregnant woman, nor do they cover other factual situations that may occur outside the treatment facilities.

\section{CONCLUSION}

It is difficult to accept the current solution, according to which life and human health at birth are covered by a broader and therefore fuller scope of protection, while a comparable degree of protection is refused to an unborn child. The observation that the relevant civil-law regulations are not sufficient to protect one of the most important values represented by human health and life seems adequate, especially when we speak of the legal interests of the conceived child. Adequate remedies under criminal law must be ensured to highlight the nature of the protected interests. Only in this way will the full extent of legal protection be guaranteed. Therefore, the proposal to amend Article 157a PC by extending criminal liability to the perpetrators of unintentional acts seems correct. In spite of a few proposed changes, only the first concept seems to guarantee the widest legal protection, as it provides for the construction of a common crime and covers the widest scope of criminalisation.

\section{BIBLIOGRAPHY}

\section{SOURCES OF LAW}

Convention on the Rights of the Child, adopted by the United Nations General Assembly on November 20, 1989. Journal of Laws of 1991, No. 120, item 526.

Ustawa z dnia 30 sierpnia 1996 r. o zmianie ustawy o planowaniu rodziny, ochronie płodu ludzkiego i warunkach dopuszczalności przerywania ciąży oraz o zmianie niektórych innych ustaw [Act of 30 August 1996 amending the Act on family planning, protection of the human foetus and the conditions for termination of pregnancy and amending certain other acts]. Journal of Laws No. 139, item 646.

Ustawa z dnia 5 grudnia 1996 r. o zawodach lekarza i lekarza dentysty [Act of 5 December 1996 on the professions of physician and dental surgeon]. Journal of Laws of 1997, No. 28, item 152.

Constitution of the Republic of Poland of 2 April 1997. Journal of Laws No. 78, item 483, as amended.

Ustawa z dnia 6 czerwca 1997 r. Kodeks karny [Act of 6 June 1997—the Penal Code]. Journal of Laws, item 2204 as amended. 
Ustawa z dnia 8 lipca 1999 r. o zmianie ustawy Kodeks karny oraz ustawy o zawodzie lekarza [Act of 8 July 1999 amending the Penal Code and the act on the medical profession]. Journal of Laws No. 64, item 729.

Ustawa z dnia 15 kwietnia 2011 r. o działalności leczniczej [Act of 15 April 2011 on medical activity]. Journal of Laws No. 112, item 654.

\section{CASE LAW}

Judgement of the Constitutional Tribunal of 28 May 1997, file ref. no. K 26/96. OTK ZU of 1997, no. 2, item 19.

Judgement of the Constitutional Tribunal of 1 June 1999, file ref. no. K 20/98. OTK ZU of 2001, no. 5 , item 93 .

Judgement of the Constitutional Tribunal of 9 October 2001, file ref. no. K 8/00. OTK ZU of 2001 no. 7, item 211.

Judgement of the Constitutional Tribunal of 7 January 2004, file ref. no. K 14/03. OTK ZU No. 1/A/2004, item 23.

Judgement of the Grand Chamber of the European Court of Human Rights in the case of Vo v. France, 8 July 8 2004, application no. 53924/00.

Judgement of the Supreme Court of 18 July 2007, file ref. no. WA 27/07. OSNwSK of 2007, no. 1 , item 1682 .

Decision of the Supreme Court of 30 October 2008, file ref. no. I KZP 13/08. OSNKW of 2008, no. 11, item 90.

Decision of the Supreme Court of 5 November 2014, file ref. no. V KK 162/14.

Judgement of the Supreme Court of 11 October 2016, file ref. no. III KK 123/16.

Judgement of the Court of Appeal in Gdańsk of 27 April 2017, file ref. no. II Aka 95/17, LEX no. 2372259.

\section{DRAFT LAWS AND THEIR JUSTIFICATIONS}

Projekt ustawy o zmianie ustawy Kodeks karny oraz niektórych innych ustaw wraz z projektami aktów wykonawczych z 18 maja 2007 r. [Draft law amending the Penal Code and certain other acts together with draft executive acts of 18 May 2007]. 5th Sejm, Sejm paper no. 1756.

Uzasadnienie do projektu ustawy o zmianie ustawy Kodeks karny oraz niektórych innych ustaw wraz z projektami aktów wykonawczych z 18 maja 2007 r. [Explanatory memorandum to the draft act amending the Penal Code and certain other acts together with draft executive acts of 18 May 2007]. 5th Sejm, Sejm paper no. 1756.

Projekt Komisji Kodyfikacyjnej Prawa Karnego ustawy o zmianie ustawy Kodeks karny oraz niektórych innych ustaw z 5 listopada 2013 r. [Criminal Law Codification Commission's draft act amending the Penal Code and certain other act of 5 November 2013]. Accessed December 27, 2017. https:Ilbip.ms.gov.pl.

Uzasadnienie projektu ustawy o zmianie ustawy Kodeks karny [Explanatory memorandum to the draft act amending the Penal Code]. Czasopismo Prawa Karnego i Nauk Penalnych 17, no. 4 (2013): 76-77. 


\section{LITERATURE}

CIEŚLAK, Wojciech. Prawo karne. Zarys instytucji i naczelne zasady. Warszawa: Wolters Kluwer, 2010.

CZEBotAR, Łukasz, and Zuzanna GĄDZIK. "Prawnokarna ochrona życia i zdrowia dziecka poczętego w ustawodawstwie polskim.” Kościót i Prawo 2 (2013): 243-70.

GARDocki, Lech. Prawo karne. Warszawa: Wydawnictwo C.H. Beck, 2017.

GIEZEK, Jacek. "Rozdział XIX. Przestępstwa przeciwko życiu i zdrowiu.” In Kodeks karny. Część szczególna. Komentarz, edited by Jacek Giezek, 225-29. Warszawa: Wolters Kluwer Polska, 2014.

GóRSKI, Adam. "Prawnokarne problemy określania relacji lekarz-pacjent z uwzględnieniem orzecznictwa Sądu Najwyższego (kwestie ogólne)." In Studia i Analizy Sądu Najwyższego, edited by Krzysztof Ślebzak, 6: 309-31. Warszawa: Lex a Wolters Kluwer business, 2012.

GrZEŚKOWIAK, Alicja. "Rozdział I. Zasady odpowiedzialności karnej.” In Kodeks karny. Komentarz, edited by Alicja Grześkowiak and Krzysztof Wiak, 3-156. Warszawa: Wydawnictwo C.H. Beck, 2017.

Hryniewicz-Lach, Elżbieta. "Przestępstwa z niewiedzy lub zapomnienia." Ruch Prawniczy, Ekonomiczny i Socjologiczny 77, no. 4 (2015): 173-86.

KARKowska, Dorota. Prawo ochrony zdrowia w pytaniach i odpowiedziach-prawa pacjenta. Warszawa: Wolters Kluwer, 2008.

KARLIKOWsKI, Dawid. “Odpowiedzialność cywilna placówki medycznej a odpowiedzialność cywilna lekarza-zarys problemu w kontekście analizy przypadku." Rozprawy Ubezpieczeniowe 18, no. 1 (2015): 32.

Krajewski, Radosław. Prawa i obowiazki seksualne matzonków. Studium prawne nad norma i patologia zachowań. Warszawa: Wolters Kluwer, 2009.

ŁAGODZIŃSKI, Stanisław. "Przestępstwo nieumyślnego spowodowania śmierci człowieka (art. 155 k.k.). Rozważania teoretyczne i praktyka ścigania.” Prokuratura i Prawo 7-8 (2014): 57-78.

Marcinkowski, Tadeusz. Medycyna sądowa dla prawników. Szczytno: Wyższa Szkoła Policji w Szczytnie, 2010.

MAreK, Andrzej. Kodeks karny. Komentarz. Warszawa: Wolters Kluwer Polska, 2006.

NYKIEL, Magdalena. "Nieumyślne przestępstwa aborcyjne-uwagi de lege ferenda na marginesie wyroku SN-Izba Karna z 27 wrzesień 2010 r. (V KK 34/10)." Czasopismo Prawa Karnego i Nauk Penalnych 16, no. 2 (2012): 65-85.

SZWARCZYK, Maciej. “Część szczególna. XIX. Przestępstwa przeciwko życiu i zdrowiu. Art.157a. Uszkodzenie ciała dziecka poczętego." Kodeks karny. Komentarz, edited by Tadeusz Bojarski, 361-63. Warszawa: LexisNexis, 2012.

WiaK, Krzysztof. "Część IV. Część szczególna. Rozdział III. Przestępstwa przeciwko życiu i zdrowiu. § 126. Spowodowanie uszczerbku na zdrowiu (art. 156-157a k.k.).” In Prawo karne, edited by Alicja Grześkowiak, 318-20. Warszawa: Wydawnictwo C.H. Beck, 2012.

WIAK, Krzysztof. Ochrona dziecka poczętego w polskim prawie karnym. Lublin: Redakcja Wydawnictw Katolickiego Uniwersytetu Lubelskiego, 2001.

WolińsKA, Magdalena. “Odpowiedzialność karna lekarza za błąd w sztuce lekarskiej.” Prokuratura i Prawo 5 (2013): 19-35. 
WoŁoszyn-Cichocka, Agnieszka, and Grzegorz Lubeńczuk. "Działalność lecznicza-pojęcie oraz formy i zasady wykonywania.” Studia Iuridica Lublinensia 23 (2014): 65-87.

ZoLL, Andrzej. Komentarz do art. 157a k.k.. LEX/el. 2013, no. 172271.

\author{
CONTENTIOUS ISSUES RELATED TO THE PERPETRATOR \\ OF AN OFFENCE INVOLVING BODILY HARM \\ OR A DISTURBANCE OF HEALTH IN A CONCEIVED CHILD
}

\title{
Summary
}

The Polish legislator has regulated the personal side of the offence of bodily injury in a child conceived in a manner different from the regulations adopted for crimes related to causing injury to the health of a born person. In the current legal framework, inadvertent harm to a conceived child or life threatening health disorder is not criminalised. Such a state of affairs leads to the issue of a possible amendment of Article 157a of the Penal Code regarding the punishability of unintentional acts. It seems (taking into account the birth criterion) that the legislator differentiates the protection of legal goods in the form of human life and health. It is indisputable that criminal law is an ultima ratio, applied when other legal means are not adequate to the rank of the protected good. However, despite the fact that there are civil regulations on this subject, it seems that they are not a sufficient means of protecting the legal goods in question. For this reason, this discourse proposes several solutions with regard to the subjective part of the offence of Article157a PC.

Key words: criminal law; conception; protection of life conceived; ultima ratio of criminal law; institution of guilt.

\section{Translated by Tomasz Pałkowski}

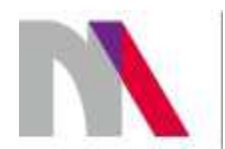

The preparation of the English version of Roczniki Nauk Prawnych (Annals of Iuridical Sciences) and its publication in electronic databases was financed under contract no. 836/PDUN/2018 from the resources of the Minister of Science and Higher Education for the popularization of science. 